inOedia $\quad \begin{aligned} & \text { InMedia } \\ & \text { The French Journal of Media Studies }\end{aligned}$

2| 2012

Performing/Representing Male Bonds

\title{
Losing Visibility? The Rise and Fall of Hypermasculinity in Science Fiction Films
}

\section{Marianne Kac-Vergne}

\section{(2) OpenEdition}

1 Journals

\section{Electronic version}

URL: http://journals.openedition.org/inmedia/491

DOI: 10.4000/inmedia.491

ISSN: 2259-4728

\section{Publisher}

Center for Research on the English-Speaking World (CREW)

\section{Electronic reference}

Marianne Kac-Vergne, "Losing Visibility? The Rise and Fall of Hypermasculinity in Science Fiction Films », InMedia [Online], 2 | 2012, Online since 06 December 2012, connection on 07 September 2020. URL : http://journals.openedition.org/inmedia/491 ; DOI : https://doi.org/10.4000/inmedia.491

This text was automatically generated on 7 September 2020

(C) InMedia 


\title{
Losing Visibility? The Rise and Fall of Hypermasculinity in Science Fiction Films
}

\author{
Marianne Kac-Vergne
}

1 In the 1980s, science-fiction became one of the privileged vehicles for a new representation of masculinity in Hollywood which can be associated with hypermasculinity, building on Lynne Joyrich's analysis of Miami Vice which sees hypermasculinity as an "excess of maleness acting as a shield" against feminization implied by becoming the object of the look, hypermasculinity thus becoming "the underlying structure of male spectacle"1. Drawing also on Varda Burstyn's use of the term to describe "an exaggerated ideal of manhood linked [...] to the role of the warrior", ${ }^{2}$ I will use the term here to emphasize an excessive yet glorified representation of masculine attributes implying a heightened visibility of the male body as spectacle while associating masculinity with dominance, violence and physical force. Hypermasculinity is therefore only one model of masculinity among others - a set of cultural norms and expectations about what men ought to be from a position of power within an unequal system of gender relations. However, hypermasculinity can be considered as hegemonic within the context of 1980s America, when "hard bodies" became the dominant model, as Susan Jeffords demonstrates in Hard Bodies, Masculinity in the Reagan Era, ${ }^{3}$ dominating other masculinities (especially non-white) as well as women. ${ }^{4}$

2 The most striking aspect of hypermasculinity in 1980s Hollywood is the visibility of the male body and specifically the spotlighting of muscles as 'natural' signs of masculine power ${ }^{5}$, prominently so in cyborg science fiction films. Hypermasculinity puts masculinity on show by making muscles highly visible: hypermasculine heroes often wear tight and revealing clothes, like Dolph Lundgren in Masters of the Universe (Gary Goddard, 1987), or no clothes at all, like Arnold Schwarzenegger in his first appearance in The Terminator (James Cameron, 1984) - even Robocop's metallic armor reproduces a body-built torso by incorporating sculpted titanium pectorals (RoboCop, Paul 
Verhoeven, 1987). The central question of science fiction, what it is to be a Man, i.e. a human opposed to non-humans, thus seems to be reformulated into a more specific questioning about what it means to be a man, or how to define masculinity. Through close textual analyses of four major science fiction films of the 1980s and 1990s, this paper wishes to examine the changing representations and definitions of masculinity offered by science fiction in the two previous decades and its relationship to hegemonic masculinity - how science fiction provided a specific hegemonic model in the 1980s in the guise of hypermasculinity while at the same time highlighting its flaws, which led to its transformation and seeming demise in the late 1990s, with the appearance of alternative models of masculinity. Were the hypermasculine "hard bodies" of the 1980 s always presented as the masculine ideal in science fiction films such as RoboCop or The Terminator? Can science fiction provide alternative models of masculinity? Can it even call into question male hegemony?

The visibility and excesses of hypermasculinity have often been and can assuredly be interpreted as a strident reassertion of male power and domination. ${ }^{6}$ Science fiction's "invincible armored cyborgs" seem to have realized the male fantasy of physical invulnerability, best embodied by the cult figure of the Terminator, played by former Mr Universe Arnold Schwarzenegger. Yet if the Terminator emblematizes male power, a perfect male body pitted against more vulnerable opponents, it is first and foremost a machine, and a terrifying one at that in the first opus of the series. Films like The Terminator but also RoboCop indeed contain an inherent critique of hypermasculinity which critics like Susan Jeffords or Claudia Springer have generally missed. In fact, the Terminator of the first opus is the enemy, a cyborg killer devoid of any human weakness - a hypermasculine soldier gone wrong. So wrong indeed that it comes back surprisingly as the 'good guy' in Terminator 2: Judgment Day (James Cameron, 1991). The Terminator's transformation has a lot to do with Schwarzenegger's shrewd careerism and confirmed star status, but also with changing definitions of masculinity in American society and the celebration of a more sensitive and nurturing "New Man", as Susan Jeffords argues in broad strokes without close textual analysis in "Can Masculinity Be Terminated?". Taking up where Jeffords left it, this article ends by examining the second Terminator's legacy in terms of masculinity. Indeed, the Terminator's evolution signaled the end of hypermasculinity in the 1990s and the rise of less visibly masculine heroes in science fiction, culminating in the feminized figure of Neo in The Matrix (the Wachowskis, 1999), whose very name asserts the victory of the New Man. Thus, whereas the Terminator's hypermasculinity stands out as highly visible in 1984, the singularity and visibility of the male body, as well as the opposition between masculinity and femininity tends to be erased in the 1990s, as exemplified by the Terminator's reinvention and (limited) demasculinization and Neo's feminization, in parallel with the masculinization of their female counterparts, Sarah Connor (Linda Hamilton) and Trinity (Carrie-Ann Moss). Can this loss in visibility restore gender balance or at least offer an alternative model of masculinity within science fiction film?

\section{Hegemonic Hypermasculinity}

Hypermasculinity relies heavily on the display and control of the male body, for which muscles, especially biceps and pectorals, function as a synecdoche. Hypermasculinity thus appears as the net result of the male actors' often highly publicized bodybuilding, 
even though the process itself is never shown onscreen, so that the heroes' physical strength remains 'natural'. Hypermasculinity, despite its excessiveness, paradoxically goes back to an essentialist definition of masculinity as both active and naturally powerful. Within an ideology which associates masculinity with activity, the emphasis on bodybuilding as a process of physical training and transformation allows male stars to display their bodies without being feminized, since, as Richard Dyer puts it, "The muscle man is the end product of his own activity of muscle-building". ${ }^{8}$ Furthermore, according to Dyer, muscles are read as signs of male power, hence naturalizing male hegemony:

The potential for muscularity in men is seen as a biological given, and is also the means of dominating both women and other men who are in competition for the spoils of the earth. The point is that muscles are biological, hence 'natural' [...]. The 'naturalness' of muscles legitimizes male power and domination.'

The visibility of the male body in hypermasculine science fiction films can thus be seen as reinforcing and justifying male hegemony, which is something men have actively strived for and therefore somehow 'deserve'. In this way, hegemonic masculinity gains its value from being 'hard', both resistant and difficult to attain.

6 Indeed, in 1980s science fiction, power, toughness and integrity are most often reserved to white male heroes. Minority members are secondary characters who can sometimes help the hero but usually disappear during the course of the action, leaving the white hero to fight on his own. The only prominent woman in RoboCop, Lewis (Nancy Allen), Murphy/Robocop's partner, is cast as a supporting role in all its meanings: she is constantly supportive of Robocop, a witness to his suffering heroism, but secondary and powerless - she does not eliminate any of their adversaries in the final shoot-out and is instead shot down, disappearing from the last scene of the film. In Predator (Mc Tiernan, 1987), Dutch (Arnold Schwarzenegger) is aided by a group of soldiers including two Black men and a Native American, who are all brutally slaughtered, while Robocop and The Terminator both feature the traditional and ubiquitous African-American police captain, well-meaning but powerless and ineffectual. Yet, what is especially striking in RoboCop, despite its progressive credentials and its satire of the Reagan era, ${ }^{10}$ is the way it participates in the demonization of ethnic and racial minorities through its portrayal of its "bad guys", a gang of sadistic drug-trafficking criminals responsible for hundreds of deaths. The gang, headed by a bespectacled white man, otherwise includes an African-American, a Hispanic, an Asian-American and an ethnic White whose name, Emil Antonowsky, emphasizes his foreign origin. All are associated to the errant and degenerate "soft body" described by Susan Jeffords and quoted above (note 3). The African-American poses and laughs hysterically, and is stereotyped as a 'stud' when he distracts Lewis by showing her his penis and then boasting about his feat. The Hispanic is arrested by Robocop in a night-club full of undulating and scantily-clad bodies. All deal and consume cocaine. In a striking and gore image, the degeneracy of these criminal bodies is underlined at the end of the film when Emil crashes into a tank of toxic waste and transforms into a monster, his shredded body liquefied by the acid.

7 The gang is moreover constantly associated with the decay of Detroit, gangrened by criminality. Their headquarters are in a dilapidated industrial zone and they take great pleasure in destroying the city during the police strike: Emil breaks the window of a TV shop only so he can listen to his favorite show while the African-American burns down a car to test his new 'toy', a military mortar. Thus, although the film criticizes Reaganite America by emphasizing the corruption of elites who are in collusion with 
the drug-traffickers, it nevertheless clearly associates the decay of America's downtowns with a rising criminality attributed to ethnic minorities. Indeed, RoboCop directly refers to the financial crisis affecting US cities in the 1980s, abandoned by those who could move to the suburbs and deeply affected by the federal cuts to urban renewal subsidies approved by Reagan, ${ }^{11}$ where insecurity became a major issue. For Roger Ebert, reviewer for the Chicago Sun-Times, part of the film's social satire comes from the proximity between Robocop and Bernhard Goetz, ${ }^{12}$ a white man who killed four black men in 1984 in New York's subway because he thought they were going to attack him. Goetz, who gave himself up to the police while pleading self-defense, was dubbed "the subway vigilante" and became a hero in the eyes of many New-Yorkers and Americans sick of the rising criminality and the inefficiency of the police. ${ }^{13}$ In spite of itself, Robocop falls partly into a Reaganite discourse which opposes a hypermasculine white protagonist to ethnically marked criminals, in a context of violence where lone vigilantes are celebrated as heroes.

\section{The Dark Side of Hypermasculinity}

However, through its satire of the excesses of Reaganism, RoboCop also underlines the negative and coercive aspects of hypermasculinity - the transformation of the male body into a machine is imposed to the hero by a corporation which has no regard whatsoever for human dignity and treats policemen like disposable human resources to be replaced by technology. In fact, Murphy's (Peter Weller) transformation into Robocop is harrowing and pathetic, as it insists on the character's powerlessness and passivity through the use of subjective camera erasing the hero's presence. Murphy is seen arriving to the hospital by ambulance, transported on a stretcher, while the camera alternates between close-ups on his bloody face and subjective shots on oxygen balloons and hospital figures. Doctors can be heard speaking off-screen, their words resonating at a distance, while the camera is on Murphy's open but vacant eyes. Subjective shots again show faces bending down over him, tubes being inserted into his mouth and a flashlight shone in his eyes. His last human memories of his wife and son are dissociated from the soundtrack, which is still dominated by the intensive care staff's barely comprehensible dialogue. The camera then tracks out quickly, leaving in the distance his wife and son waving goodbye, highlighting the arrival of death and the corollary erasure of Murphy's past, to finish on a close-up on Murphy's fixed stare. His final memory is one of pain, the pain of his execution revived in a flashback by the electric shock of the defibrillator, before a final fade out to the prosaic words of a doctor announcing, "All right, I think that's all we can do, let's call it. What's the time?". At the end of a painful process of erasure depriving the protagonist of any agency and heroism, the human Murphy is dead.

The next scene shows his rebirth as a robot, but again, Robocop is completely passive, childlike. Technicians have replaced the doctors and are also filmed in subjective shots, only this time through a computer screen reproducing Robocop's digital vision. They can be seen bending over him to adjust his screen, before a technician proudly announces to the project manager that they have been able to save Murphy's left arm, only to be rebuffed, "What? I thought we agreed on total bodily prosthesis! Now lose the arm." The company's project is clear: all traces of Murphy's humanity must disappear so that only the machine is left. Robocop is constantly belittled by the team 
who built him - the manager contemptuously snaps his fingers to attract his attention - and is considered as an object or at best as a child, which visually translates into repeated low-angle shots on characters bending over him, like the manager, whose face is shot in a distorting extreme close-up as he exhorts Robocop to be "a bad motherfucker", projecting his own hegemonic fantasies onto him. Hypermasculinity in Robocop is thus shown to be the result of a long and painful process which transforms a human being into a machine, an object owned by the company which initiated the process. The hardening and mechanization of the male body is indeed fulfilled in the absence of any conscious decision on the part of the hero, who remains motionless and powerless throughout his operation, introducing an element of pathos in this unwilling robot.

The characteristics of hypermasculinity become even more problematic, and frightening, in The Terminator, which pushes the logic of male hegemony to the extreme - the hypermasculine male loses all humanity, seeking to eliminate a woman who is a threat because of her reproductive capacities. The Terminator is indeed characterized by its invulnerability, relentless determination and complete indifference to suffering, transforming the hypermasculine male into a terrifying monster and exploring the perils of hegemonic fantasies of male omnipotence. As James Cameron himself underlines, Arnold Schwarzenegger's embodiment of the Terminator is all the scarier because he represents "a perfect male figure". ${ }^{14}$ The Terminator indeed shows the flip side of an ideal model of masculinity built as hard, violent and invincible. The cyborg looks like a human being and is played by one, but the film reveals that its human skin hides a computer-programmed metallic endoskeleton.

11 Moreover, Arnold Schwarzenegger's naked body is itself akin to a machine, a body sculpted and molded by years of bodybuilding. Jérôme Momcilovic ${ }^{15}$ convincingly demonstrates the fundamental otherness of Schwarzenegger's body and the influence of the doctrine of mechanism on its representation, two aspects which are clearly underlined in his first appearance in The Terminator. The film opens on the continuous noise of machines over close-ups on the metallic parts of a garbage truck, highlighting from the start the film's insistence on mechanization. After a bolt of lightning, a naked body appears, kneeling in a foetal position before slowly unfolding to reveal sculpted pectorals and glinting skin, the low angle shot emphasizing its massive build. The head then slowly turns from right to left, scanning its environment methodically, without any emotion showing on an inexpressive face. Finally the body walks forward beyond the camera to end in a long shot where Schwarzenegger's body stands stiffly like an illuminated statue of a conqueror examining the city lying at his feet. Masculine perfection is so terrifying that it becomes horrific as the indestructible Terminator lacks any feelings of pity, compassion or remorse. Yet, this cyborg is unquestionably virile and embodies certain qualities traditionally associated with masculinity, such as physical strength, terseness and tenacity.

12 Like a monstrous Hercules, the Terminator unveils the dark side of masculinity, as evidenced by the film's editing, which goes back and forth between the Terminator and the other white man of the film, Kyle Reese (Michael Biehn). Kyle's arrival is also announced by lightning, he is naked and immediately goes hunting for clothes and weapons, like the Terminator. Kyle is so traumatized by the victory of the machines that he has become mechanical himself and is incapable at first of understanding human emotions, like Sarah's initial fear and then growing tenderness towards him. 
Kyle dangerously resembles the Terminator, whom he stalks, flees and imitates, valuing fighting and violence over emotions, even though the film also insists on his human weaknesses, especially his physical pain. Too close to the machines, Kyle will therefore not be the savior of humanity, a role delegated to Sarah, whose feminine qualities are more clearly opposed to the machines - innocence and naivety at first, then her ability to express emotions and finally (and most importantly) her female ability to bear a child.

\section{Revising Hypermasculinity}

One can wonder if the terrifying aspects of the hypermasculine Terminator were so problematic that the character had to be revised and transformed in a second opus, Terminator 2: Judgment Day, released in 1991. The Terminator who seeks to eliminate Sarah Connor in the first film indeed comes back in the second (still played by Schwarzenegger) as a 'good guy' whose mission is to protect the teenage John Connor (Edward Furlong), Sarah's son. The change is certainly a result of Schwarzenegger's success and career move away from violent and 'serious' action films into the realm of comedy, starring in films such as Twins and Kindergarten Cop (Ivan Reitman, 1988, 1990) where he is no longer a menace but a reassuring presence. As GQ put it in May 1990, "[Schwarzenegger] transformed the image of bodybuilding from one of excessiveness and narcissism to one of heroism and health" ${ }^{16}$ But it is also linked to changing definitions of masculinity in US public discourse at the time, which turned away from rugged, aggressive and determined fighters to celebrate sensitive "New Men" more in tune with Bush's "gentler, and kinder nation". ${ }^{17}$ The generally-accepted definition of the New Man in the 1990s is summarized as follows by Pierrette Hondagneu-Sotelo et Michael A. Messner, "He is a white, college-educated professional who is a highly involved and nurturant father, 'in touch with' and expressive of his feelings, and egalitarian in his dealings with women". ${ }^{18}$ Even if the Terminator is not quite the college-educated professional, Terminator 2 does reorient the focus of the franchise onto the relationship between the Terminator and a teenager and his mother, centering on a reconstituted nuclear family. The Terminator's protective and increasingly fatherly relationship to John thus allows him to change from a violent and emotionless machine, the embodiment of hypermasculinity gone bad, into a nurturing and humanized father-cyborg.

The Terminator's metamorphosis is interestingly played out in his first confrontation with his enemy, the T1000 (Robert Patrick), when both are looking for John. When the Terminator appears to John, he is shot in slow motion on a musical theme dominated by percussions recalling the first film (although the presence of bells hint at a transformation by adding a melodic touch to the harsh drum rolls of The Terminator). He strides forward with the same determination as in the first opus, and takes out a shotgun from a box of roses, trampling the flowers in his stride as a symbol of his contempt for human emotions and organic fragility. John's terror at his sight seems at first to validate the reappearance of the Same, yet his flight confronts him to a much more dangerous Other, musically announced by the replacement of the bells by the repetitive purring of a machine, the T1000's theme, as the latter appears at the end of a corridor. As the T1000 manifests an otherness even more inhuman than the Terminator's, his fluid body pierced by holes immediately coagulating and 
regenerating, the Terminator's superhuman and menacing body becomes a protective one. Lethal weapon turned shield, the Terminator indeed uses his bulletproof metallic body to protect John, holding him in his arms away from the T1000 as a protective father would. Playing with the principle of repetition at the core of a franchise, Terminator 2 pretends to repeat but in fact reverses, so that it redefines the monstrous hypermasculinity of the first episode as vigilant paternity, validating the hegemonic hypermasculinity of the 1980 s that the first opus criticized.

The relationship between the Terminator and John indeed becomes increasingly close and even tender, as the two characters repeatedly touch each other, be it when John initially puts his fingers in the bullet holes in the Terminator's back and presses the 'skin' of his cheek, or in the final hug, when the Terminator presses John against him before going to his death. The Terminator becomes the embodiment of exemplary fatherhood, an ever-present protector who is close to his 'son' yet always ready to defend him, as underlined by the many shots of him standing watchfully, legs apart, gun in hand, scanning the horizon day and night. The Terminator's terrifying determination in The Terminator thus becomes his primary quality in Terminator 2 . He displays only the advantages of hypermasculinity: he uses his strength to defend his family and never turns against it, contrary to Sarah's past macho, violent and irresponsible boyfriends. By combining the best of hypermasculinity and of the New Man, the Terminator represents an ideal father, loved by John and even validated by Sarah in her voice-over (he is also nicknamed "Uncle Bob", i.e. Sarah's lover), enabling the formation of a united nuclear family and revising the hypermasculine man of the 1980 s to present him as a responsible and integrated father.

Moreover, associating a massive, rigid and mechanical Terminator to a diminutive, mischievous and alert teenager allows the film to take its distances from hypermasculinity and safely demasculinize, to a certain extent, the character played by Schwarzenegger. The film indeed includes many humorous touches from the moment when John realizes that the Terminator has to obey him. The killing machine becomes a toy, a harmless robot who stands on one leg when ordered to, a simple thus likeable hulk. Whereas The Terminator used horror to harden its Terminator, Terminator 2 turns to comedy to soften him, as when the Terminator stiffly repeats what John teaches him, like a father learning the language of his teenage son. "Hasta la vista, baby", pronounced staccato and in a wooden voice by the Terminator, actually became one of America's most famous movie quotes, a humorous answer to The Terminator's terrifying and equally famous "I'll be back" ${ }^{19}$ Terminator 2 incorporates parody to mitigate the Terminator's hypermasculinity - John ridicules his unflinching seriousness by calling him a 'dork', while the film mocks Schwarzenegger's 1980s warrior persona in films like Predator and Commando in a short freeze frame shot on the Terminator posing with a huge machine gun, half smiling, to which John nods, declaring "That's definitely you!". The pairing of the Terminator with John brightens up the serious hypermasculine heroes of the 1980s and offers a revised, less domineering, more flexible model of masculinity - the Terminator learns to say "no problemo" instead of the traditional military term "affirmative", derided by John.

Terminator 2 thus refocuses midway on the humanization of the Terminator, who becomes the narration's main center of attention. First, his body is humanized. As opposed to the gory scene in The Terminator where the Terminator repairs his own eye, in Terminator 2, he is nursed by Sarah and the audience does not see the machine under 
the skin, since his wounds are covered by bandages. During the course of the film, the machine is uncovered little by little, revealing the metal under the skin, but his body remains recognizably human until the end, contrary to the metallic skeleton at the end of The Terminator and the subhuman T1000, a shapeless body of liquid metal. In spite of his wounds, the Terminator keeps the same distinctive humanoid body throughout the film, and affirms human dignity by remaining upright until the end, which the camera celebrates by a final close-up on his upturned thumb. The last sequence gives the Terminator the moral high ground by emphasizing his experience of physical pain (the new Terminator does register pain as digital information) and mental sorrow, canonizing him as hypermasculinity's martyr.

The ultimate confrontation between the Terminator and the T1000 becomes the former's martyrdom, as he is thrown against the walls, dismembered, clubbed and crushed before collapsing on the floor and crawling desperately, arousing the viewer's pity. The camera zooms in and focuses on his mutilated and bloodied face, then on the stump of his arm. His difficult progress is halted by the T1000 piercing his body with a stake, his intense pain underlined by a discomforting soundtrack dominated by discordant chords interrupted by cymbals. The T1000's last strike comes with lightning and thunder and the Terminator stops, to a suspended musical cadence, the length of the last chord indicating the end of the scene and the Terminator's (apparent, hence the suspended cadence) death. Nailed to the ground as Jesus was to the cross, the Terminator is thus presented as an expiatory victim. After his resurrection, physical pain is superseded by moral anguish, marking him as human and as a New Man capable of expressing emotion. The Terminator indeed realizes with deep sadness that he will never be able to cry and therefore be fully human. In a scene full of pathos, as John sobs and is comforted by the Terminator who wipes the tears off his cheek, the latter is able to see the limits of his mechanical being, and this consciousness raises him above the machine to make him partly human. This human dimension is confirmed by a selfsacrifice which transcends the limits of his program - the Terminator acquires his humanity by becoming its savior.

Whereas the Terminator was presented mainly as a terrifying object in The Terminator, he becomes a subject in Terminator 2, a process hinted at in his very first appearance and fully confirmed in his ultimate one. Indeed, in The Terminator's opening scene, the camera adopts a contemplative stance, presenting the Terminator in long and steady shots, often medium or medium-long shots. In Terminator 2 however, the camera moves and the shots become shorter, and most importantly, the Terminator, after the same close-up on his head scanning the horizon from right to left, is granted a subjective shot - we see what he sees, and the image shows not his body, but his digital vision of motorcycles parked in front of a bar. The audience is thus given access to his consciousness. The film is dotted with such digital shots showing the Terminator's specific point of view, for example when he recognizes John or when he comes back to life. Yet, they disappear from the ultimate scene showing the Terminator's death. The final shots and reverse shots alternate between what Sarah and John are seeing, the Terminator descending to certain death in molten metal, and the last visions of the Terminator, notably a low-angle point-of-view shot showing Sarah and John on the platform above, at a distance. This shot is not digitalized and thus completes the humanization of the Terminator, who can finally see the world with human eyes. 
The Terminator thus becomes the focal point of the second opus, overshadowing the other characters. He may be a sensitive father included in a nuclear family, a tolerant and responsible cyborg willing to cooperate with others, yet these Others - AfricanAmerican Dyson, female Sarah, teenage John - are systematically presented as weaker, being as they are 'inferior' on a hegemonic ladder still dominated by the strong white male. Thus the fatherly Terminator finally replaces Sarah as John's guardian, outshining her both as a parent and as a warrior. Previously fiercely combative and source of the voice-over, Sarah remains mostly silent during the whole of the last sequence, even losing her voice to the T1000, who impersonates her to attract John. Confronting her evil alter ego, she runs out of bullets and is unable to defeat him and protect her son. Only the arrival of the better-armed Terminator eliminates the T1000 and saves John. Aggressive and lacking in maternal tenderness, Sarah cannot compete with the Terminator's fighting skills, and therefore loses on both fronts. The Terminator thus sidelines his female partner while appropriating her parental function and maintaining his male power - validating Lynne Segal's claim that "the contemporary revalorisation of fatherhood has enabled many men to have the best of both worlds", ${ }^{20}$ emotional well-being as well as continued dominance. Terminator 2 nevertheless represents a turning point in the representation of masculinity, reflecting the evolution of gender norms in contemporary American society as it marks the transition from 1980s hypermasculinity to the New Man of the 1990s. By 'terminating' hypermasculinity and introducing a partnership with a masculinized woman, it paved the way for a change in the representation of the male body and gender relations initiated in such films as Strange Days (Bigelow, 1995), Johnny Mnemonic (Longo, 1995) or Gattaca (Niccol, 1997), culminating in the huge box office success of the end of the decade that was The Matrix (Wachowski, 1999).

\section{The End of Hegemonic Hypermasculinity? A New Model}

21 The Matrix's mise en scène of its hero, Neo (Keanu Reeves), presents an image of masculinity in complete contrast with the visibility of hypermasculinity, blurring the stereotyped distinctiveness of the male body and inverting traditional gender roles. Moving away from the mechanically-enhanced 'invincible armored cyborgs' without relying on the comforts of fatherhood, The Matrix thus seems to offer an alternative to hegemonic masculinity by presenting a feminized hero constructed as a mirror image of his female counterpart, fulfilling perhaps the egalitarian promise of the New Man.

The beginning of the film subverts the stereotypes of the active male and the passive female, as the opening sequence showcases the action feats of a woman, Trinity (CarrieAnne Moss), while Neo first appears asleep. The first shot of Neo indeed shows a beautiful face which the spectator is invited to contemplate through the use of a very slow track-in and a trip-hop soundtrack. The next tracking shot follows in close-up the curve of his neck, first presented blurred and then in focus, to sensual effect. Keanu Reeves gives himself up passively to the camera, without seeking to offset his objectification by an active pose, contrary to the traditional representations of masculinity analyzed by Steve Neale or Richard Dyer. ${ }^{21}$ Rather than flexing his muscles, Reeves displays a feminine type of beauty with his white skin, regular features and graceful movements, which will be underlined throughout the film. In fact, his beauty 
was commented on by all critics, mostly derisively. Variety mocked him as boring "eye candy" 22 while Janet Maslin sniggered that "Keanu Reeves makes a strikingly chic Prada model of an action hero". ${ }^{23}$ Charles Taylor, one of the few critics to defend Reeves, provides an interesting explanation for the general sarcasm directed at the actor: " Reeves is one of the few contemporary male stars whose presence acknowledges that people are out there in the dark looking at him. [...] his slight languidness encourages looking. That willingness to be looked at evokes [...] a homosexual panic". ${ }^{24}$ Reeves indeed transgresses the taboo of passive male objectification, adopting the position traditionally assigned by Hollywood to women and famously described by Laura Mulvey as "to-be-looked-at-ness", ${ }^{25}$ a clearly unsettling experience for many reviewers. The way Keanu Reeves is filmed especially in the first half of The Matrix, insisting on his physical beauty and passivity, indeed subverts the conventional representation of both genders and the dominant norms assigned to them.

Neo's very first visitor, who knocks on his door to buy illegal data, almost immediately comments on his appearance, remarking that "[he] looks even whiter than usual". The image indeed contrasts the two men, Neo appearing against the cold green of the Matrix while his red-haired and rosy-cheeked visitor stands in a corridor suffused with golden lighting. Contrary to Hollywood convention, according to which the hero's skin should not be too pale and should in any case be darker than the woman's, ${ }^{26}$ in The Matrix, Neo always appears whiter than the others, his paleness enhanced by his dark clothes, his association with dark backgrounds and very dark-skinned characters such as Morpheus (Laurence Fishburne) or the Oracle (Gloria Foster). Even more interesting is the tonal similarity between Neo and Trinity's skin color, which is underlined in shots where their faces are shown right next to each other, as in the nightclub scene at the beginning of the film or the kiss at the end. In the latter, their two faces are positioned symmetrically, both in profile, so that the light shines on them in the same way, the center of their faces in the shadows while the corners of the shot (Neo's forehead and Trinity's chest) are lit, the two faces merging in the same shaded and pearly white in a shot which erases sexual difference.

The scene of the kiss also underlines Neo's passivity - throughout the film he is shown asleep or lying down, willingly or unwillingly. When taken by the agents of the Matrix, Neo is undressed and stretched on a table by two agents who forcibly insert a repulsive insect in his navel, evoking a rape scene. His pale, skinny and hairless body appears vulnerable and penetrable - most visibly when he emerges naked from the cocoon of the Matrix only to be engulfed in its core when detached from its cables, leaving gaping holes in a limp body. This weakened and perforated body must be reinforced by technology, not to turn it into an invincible cyborg, but simply to ensure its viability: Neo's atrophied muscles are rebuilt by needles planted in his inert body lying on a hospital bed. Neo and his body are thus the focus of all the other characters' attention always observed, commented on and sustained. Excepting Morpheus, Trinity and Cypher the traitor (Joe Pantoliano), the other members of the crew appear mainly as logistical support and internal spectators.

Moreover, Neo is also passive from a narrative point-of-view. He is often silent, not because he represents the strong silent type but because he is unable to express himself, as the image of his lips glued together by the agents symbolizes. Neo is generally shown listening avidly to others more knowledgeable than him - in fact, Trinity's and Morpheus's first orders are for him to be quiet and listen carefully. 
Presented as an ignorant naïve who has to be initiated, Neo is repeatedly compared to fairy tale heroines like Alice (his first order is to "follow the white rabbit"), Dorothy (Cypher warns him mockingly, "Buckle your seatbelt Dorothy, because Kansas is going bye-bye") or Sleeping Beauty, woken by Trinity's kiss. The Matrix insists on Neo's alternative masculinity by contrasting him with more virile and robust characters (Morpheus, Dozer), displaying traditional masculine attributes like facial hair (Cypher). Furthermore, Neo is submitted early on to women's authority, ordered about by Trinity and threatened by Switch (Belinda McClory), the other female crew, a masculine woman with hard features and cropped hair who points a gun at him and commands him to undress, addressing him scornfully as a "coppertop" still plugged into the Matrix. This scene in the limousine repeats and inverts the rape-like torture inflicted by the agents, with this time a woman in charge: Trinity again takes off Neo's shirt to extract the bug inserted by the agents. Neo thus loses control over his body which is first manipulated by the agents and then disinfected by women narratively and iconographically on top.

Neo therefore embodies, as his name suggests, a "new man", who rejects the norms of traditional masculinity at the same time as he abandons his Matrix-given identity preceded by a masculine title, Mr Anderson. His feminization subverts the binary division between masculine and feminine, especially since his character mirrors Trinity's, his female alter ego. The two characters look very similar, their radiant and angular white faces contrasting with their analogous black costumes. This similarity is underlined during the attack on the agents' headquarters. Indeed, they are presented almost as duplicates in the first freeze frame which ironically follows the agents' call to "Freeze!", matching from head to toe in their black pants, belts and long coats, their dark sunglasses and slick black hair combed back. Their movements are perfectly synchronized, their heads turning at the exact same moment before each darts to one side. The film then cuts from one to the other as they perform the same moves, such as a cartwheel filmed in slow motion and amplified by their long coats, before freezing on them again as they stand next to each other in the elevator at the end of the carefully choreographed battle.

However, until this scene which finally gives a slight advantage to Neo in terms of physical performance and screen time, Trinity leads the way - as Pat Mellecamp remarks, "It will take the entire film before Neo gets up to his woman's speed, fighting skills, awareness and black-leather fashion". ${ }^{27}$ The Matrix indeed begins with a spectacular action sequence on Trinity, whose voice opens the film, recalling Sarah's opening voice-over in Terminator 2 but giving access to her emotions and desires. She demonstrates a number of physical feats which Neo will then have to learn - she delivers kicks while suspended in the air, climbs walls, leaps across buildings and propels herself into very small openings, ridiculing the condescending police captain who thought his force "[could] handle one little girl". Moreover, Trinity is presented as a desiring subject, who comes into the Matrix to get the one she wants and then saves him from his death. The film highlights her desire, while Neo is only a receptacle. In the nightclub, she walks over to him with confidence, bare-shouldered, her big blue eyes steadily boring into his. She draws very close and whispers in his ear in a low sensual voice. The shots focus on her face, lit-up, smooth and collected, while the reverse shots, still centered on her neck and head, corner Neo's mobile face in halfdarkness, insisting on his uncertainty and confusion. Reminiscent of film noir's femmes fatales, Trinity however is a positive character whose desire breathes life rather than 
brings death. She is the one who kisses Neo, bending over his dead body, the camera focusing on her mouth and eyes in extreme close-up. Unconventionally, she is the bearer of the look and the eyeline match positions Neo as the one being looked at and desired, while Trinity herself is not sexually objectified. Moreover, as she resuscitates Neo, Trinity's power to give life outside the Matrix makes her, in a way, the sole real agent within the narrative logic of The Matrix, so that one can argue, like Christopher Williams, that she is the real heroine of the film, "who has made all worlds subject to herself". ${ }^{28}$

This seems to me to be an 'optimistic' reading of the film, which focuses more on Neo's progression and celebrates him as the true hero, the savior of humanity, aka "the One". $\mathrm{He}$ is the only one capable of beating the agents, as the film demonstrates in a 10minute-long stunt-packed one-on-one fight scene between Neo and Agent Smith. Furthermore, Neo's performance is especially magnified by the film's special effects the visual effect of bullet time, The Matrix's major innovation, is used repeatedly and at length for Neo's fights, emphasizing his total control of space and pointing to his omnipotence. ${ }^{29}$ However, these highly visible and unrealistic special effects also call attention to the artificial nature of the image. As he becomes the One, Neo indeed appears less human and more and more virtual, resembling a videogame character. In his last fight his movements are slow and broken-up, like an action figure's: after kicking Agent Smith, his leg stays stretched out in the air for more than 5 seconds, then pivots 90 degrees before coming down. Neo's last attack confirms his virtual nature as he dives into Agent Smith's body, shatters it and replaces him, appropriating the agents' ability, as computer programs, to embody anyone in the Matrix. The invincible and omnipotent savior of humanity that Neo has become is thus clearly marked out as a product of cinematic special effects belonging to the realm of science fiction.

The 1980s witnessed an increased visibility of masculinity, notably in science fiction films, which revised the genre's central dichotomy between humans and non-humans, including machines, to present mechanically-enhanced paragons of hypermasculinity. These hypermasculine cyborgs can be seen to embody hegemonic masculinity, responding to and sustaining a cultural ideal that emphasized male power through the highlighting of muscles, reasserting white male domination over women and ethnically-marked men. However, the characters of Robocop and the Terminator embody both "the best of" and the worst of hegemonic masculinity, revealing how constricting gender norms can transform tough indestructible warriors into inhuman monsters. Yet, as the unwilling robot-cop and the Terminator become conscious of their transformation and ontological status, the films turn them into victims, using pathos to make their continued hegemony acceptable. The evil Terminator is thus reprogrammed into a self-sacrificing protective giant whose emotional awareness and fatherly instincts introduce the New Man in the invincible armored cyborg. By revising hypermasculinity, Terminator 2 paradoxically celebrates it, focusing on the Terminator's humanization at the narrative expense of the other characters, especially the initially proactive Sarah Connor. Nevertheless, the film sparked a turn away from hypermasculinity in the 1990s and the emergence of a less visible, feminized masculinity strikingly embodied by Neo in The Matrix. By subverting conventional gender representations, The Matrix offered a new androgynous model uniting masculine and feminine representations within more equal gender relations. However, the androgynous man partnered with an active woman seems to have been a window in science fiction history, as the resurgence in the last decade of visibly virile and solitary 
heroes in films such as I, Robot (Proyas, 2004), I Am Legend (Lawrence, 2007), Iron Man (Favreau, 2008) or Captain America: The First Avenger (2011) seems to suggest.

\section{BIBLIOGRAPHY}

Review of The Matrix, Variety, 29 March 1999.

Dyer, Richard. “Don't Look Now.” Screen 23, 3-4 (1982): 61-73.

Dyer, Richard. White. London: Routledge, 1997.

Ebert, Roger. Review of RoboCop. Chicago Sun-Times, 17 July 1987.

Hondagneu-Sotelo, Pierrette and Messner, Michael A. “Gender Displays and Men's Power, the New Man and the Mexican Immigrant Man." In Theorizing Masculinities, edited by Harry Brod and Michael Kaufman. Thousand Oaks: Sage Publications, 1994, 200-18.

Jeffords, Susan. Hard Bodies: Masculinity in the Reagan Era. New Brunswick: Rutgers University Press, 1994.

Joyrich, Lynne. “Critical and Textual Hypermasculinity.” In Logics of Television: Essays in Cultural Criticism, edited by Patricia Mellencamp. Bloomington: Indiana University Press, 1990, 156-172.

Maslin, Janet. Review of The Matrix. The New York Times, 31 March 1999.

Mellencamp, Pat. "The Zen of Masculinity - Rituals of Heroism in The Matrix." In The End of Cinema as We Know It: American Film in the Nineties, edited by Jon Lewis. New York: New York University Press, 2001, 83-94.

Momcilovic, Jérôme. "L'homme extraordinaire du cinéma : Remarques sur l'œuvre d'Arnold Schwarzenegger." In Le Cinéma des années Reagan, edited by Frédéric Gimello-Mesplomb. Paris: Nouveau Monde éditions, 2007, 181-191.

Mulvey, Laura. "Visual Pleasure and Narrative Cinema." Screen, 16, 3 (Autumn 1975): 6-18.

Neale, Steve. "Masculinity as Spectacle: Reflections on Men and Mainstream Cinema." Screen, 24, 6 (1983): 2-17.

Patterson, James T. Restless Giant, the United States from Watergate to Bush v. Gore. Oxford: Oxford University Press, 2005.

Segal, Lynne. Slow Motion: Changing Masculinities, Changing Men. New Brunswick: Rutgers University Press, 1990.

Springer, Claudia. "Muscular Circuitry: The Invincible Armored Cyborg in Cinema." Genders 18 (Winter 1993): 87-101.

Taylor, Charles. "Something in the way he moves." Salon, 29 April 1999.

Williams, Christopher. "Mastering the Real: Trinity as the 'real' hero of The Matrix." Film Criticism, 27, 3, (March 2003): 2-17. 


\section{NOTES}

1. Lynne Joyrich, "Critical and Textual Hypermasculinity", in Logics of Television: Essays in Cultural Criticism, ed. Patricia Mellencamp (Bloomington: Indiana University Press, 1990), 165,168.

2. Varda Burstyn, Rites of Men: Manhood, Politics and the Culture of Sport (Toronto: University of Toronto Press, 1999), 4.

3. "Bodies were deployed in two fundamental categories: the errant body containing sexually transmitted disease, immorality, illegal chemicals, 'laziness', and endangered foetuses, which we can call the 'soft body'; and the normative body that enveloped strength, labor, determination, loyalty and courage - the 'hard body' - the body that was to come to stand as the emblem of the Reagan philosophies, politics and economies." Susan Jeffords, Hard Bodies: Masculinity in the Reagan Era (New Brunswick: Rutgers University Press, 1994), 24-25.

4. My understanding of hegemonic masculinity comes from R.W. Connell, who defines it in Masculinities (Cambridge: Polity Press, 2005) as "a way of theorizing gendered power relations among men" (xviii), "the masculinity that occupies the hegemonic position in a given pattern of gender relations, a position always contestable" (76) and "the configuration of gender practice which guarantees (or is taken to guarantee) the dominant position of men and the subordination of women" (77).

5. See Richard Dyer, "Don't Look Now," Screen, 23, 3-4 (1982): 61-73.

6. See for example Claudia Springer, "Muscular Circuitry: The Invincible Armored Cyborg in Cinema", Genders, 18 (Winter 1993): 87-101.

7. Susan Jeffords, “Can Masculinity Be Terminated?", in Screening the Male, Exploring Masculinities in Hollywood Cinema, eds Steven Cohan and Ina Rae Hark (London: Routledge, 1993), 245-62.

8. Richard Dyer, “Don't Look Now," Screen, 23, 3-4 (1982): 71.

9. Dyer, “Don't Look Now," 71.

10. A satiric tone noted by Rita Kempley in her review for The Washington Post (17 July 1987) and Roger Ebert in his review for the Chicago Sun-Times (17 July 1987). Michael Miner, one of the scriptwriters, explicitly describes Robocop as social satire in the "making of" section of the MGM Video DVD bonus (2002).

11. André Kaspi, Les Américains, tome 2, les Etats-Unis de 1945 à nos jours (Paris : Seuil, 2002), 594.

12. "And there is pointed social satire, too, as the robocop takes on some of the attributes and some of the popular following of a Bernhard Goetz." Roger Ebert, review of RoboCop, Chicago SunTimes, 17 July 1987.

13. James T. Patterson, Restless Giant, the United States from Watergate to Bush v. Gore (Oxford: Oxford University Press, 2005), 172-73.

14. "I think [the public] see [Arnold] from the beginning as this implacable, sexless, emotionless machine - in the form of a man, which is scary, because he's a perfect male figure." James Cameron, interviewed by David Chute, Film Comment, 1 (January/February 1985): 57-59.

15. Jérôme Momcilovic, «L'homme extraordinaire du cinéma : Remarques sur l'œuvre d'Arnold Schwarzenegger ", in Le Cinéma des années Reagan, ed. Frédéric Gimello-Mesplomb (Paris: Nouveau Monde éditions, 2007), 181-91.

16. Alan Richman, GQ, May 1990, 204. Quoted in Yvonne Tasker, Spectacular Bodies, Gender, Genre and the Action Cinema (London: Routledge, 1993), 81.

17. George Bush, 1988 Republican National Convention Acceptance Address, www.americanrhetoric.com/speeches/georgehbush1988rnc.htm, accessed 21 December 2011.

18. Pierrette Hondagneu-Sotelo and Michael A. Messner, "Gender Displays and Men's Power, the New Man and the Mexican Immigrant Man," in Theorizing Masculinities, eds Harry Brod and Michael Kaufman (Thousand Oaks: Sage Publications, 1994), 200-18. 
19. "I'll be back" is ranked $37^{\text {th }}$ in the AFI's top 100 movie quotes of all times, while "Hasta la vista, baby" is ranked $76^{\text {th }}$. http://www.afi.com/tvevents/100years/quotes.aspx, accessed 20 December 2011.

20. Lynne Segal, Slow Motion: Changing Masculinities, Changing Men (New Brunswick: Rutgers University Press, 1990), 58.

21. Steve Neale, "Masculinity as Spectacle: Reflections on Men and Mainstream Cinema," Screen, 24, 6 (1983): 2-17; Dyer, “Don't Look Now”.

22. "he brings no more or less than he ever does to his role, which translates into agreeable eye candy for some and boredom for others." Review of The Matrix, Variety, 29 March 1999.

23. Janet Maslin, Review of The Matrix, The New York Times, 31 March 1999.

24. Charles Taylor, "Something in the way he moves", Salon, 29 April 1999, http://www.salon.com/ent/movies/feature/1999/04/29/keanu, accessed 15 January 2010.

25. Laura Mulvey, "Visual Pleasure and Narrative Cinema”, Screen, 16, 3 (Autumn 1975): 10.

26. See Richard Dyer, White (London: Routledge, 1997).

27. Pat Mellencamp, "The Zen of Masculinity - Rituals of Heroism in The Matrix", in The End of Cinema as We Know It: American Film in the Nineties, ed. Jon Lewis (New York: New York University Press, 2001), 83.

28. Christopher Williams, "Mastering the Real: Trinity as the 'real' hero of The Matrix", Film Criticism, 27, 3, (March 2003): 17.

29. See Aurélie Ledoux, "Le cinéma américain peut-il être sceptique? Les effets de «trompel'œil » dans le cinéma américain contemporain (1984-2001)" (Doctoral dissertation, Université Paris I, 2009), 162.

\section{ABSTRACTS}

Science fiction films of the 1980s, including The Terminator and RoboCop, seem to foreground hypermasculinity as a new ideal of masculinity, relying on the display and promotion of muscular white male bodies. However, the films also highlight the negative aspects of hypermasculinity, embodied especially by the Terminator, the terrifying antagonist of the first film of the franchise. Already in the 1980s, hypermasculinity was indeed associated with a loss of humanity, so that it became incompatible with the cultural prominence of the sensitive and nurturing 'New Man' of the 1990s. Hypermasculinity was thus revised in Terminator 2 to present the formerly fearsome Terminator as a protective father undergoing a process of humanization, paving the way for new representations of masculinity and more equal gender relations in The Matrix, which plays on traditional gender roles by matching a beautiful passive hero and an athletic action heroine. The evolution of science fiction films in the 1980s and 1990s thus underlines a striking change in the representation of masculinity, from very visible and differential hypermasculinity to gender-blending androgyneity.

\section{INDEX}

Keywords: science fiction, masculinity, hypermasculinity, RoboCop, The Terminator, Terminator 2, The Matrix, United States 


\section{AUTHOR}

\section{MARIANNE KAC-VERGNE}

Marianne Kac-Vergne is an Associate Professor in American Studies at the Université de Picardie Jules Verne. She has published several articles on masculinity and Hollywood genres, most recently on contemporary gangsters in the last issue of CinémAction ( $\left.\mathrm{n}^{\circ} 143\right)$. She is currently writing a book on masculinity in contemporary science fiction (IB Tauris, forthcoming). 